\title{
Clinical, epidemiological and mycological report on 65 patients from the Eastern Amazon region with chromoblastomycosis
}

\author{
Relato clínico, epidemiológico e micológico de 65 pacientes com \\ cromoblastomicose procedentes da Amazônia oriental
}

\author{
Carla Andréa Avelar Pires ${ }^{1}$ \\ Juarez Antônio Simões Quaresma ${ }^{3}$ \\ Bruna Ranyelle de Marinho Sousa ${ }^{5}$
}

\author{
Marilia Brasil Xavier ${ }^{2}$ \\ Geraldo Mariano Moraes de Macedo ${ }^{4}$ \\ Arival Cardoso de Brito ${ }^{6}$
}

\begin{abstract}
BACKGROUnD: Chromoblastomycosis is a chronic fungal infection caused by fungi from the Dematiaceae family. According to several studies, Fonsecaea pedroso $i$ is the most common of these fungi. The infection is more common in tropical countries, with the Brazilian state of Pará having one of the largest infected populations worldwide. The disease is difficult to treat and recurrences are common.

OBjeCtives: To describe the epidemiological and mycological aspects of cases of chromoblastomycosis and its clinical forms in the state of Pará, Brazil. Methods: Mycological exams (direct mycological examinations, culture and microculture) were performed and a clinical/epidemiological evaluation was made of 65 patients receiving care at the Dermatology Department of the Federal University of Pará between 2000 and 2007. The clinical classification proposed by Carrión in 1950 was used in this study.

RESULTS: The majority of the patients were male (93.8\%), agricultural workers (89.2\%) of 45 to 55 years of age, and the majority of lesions (55.4\%) were of the verrucous type, located principally on the lower limbs (81.5\%). In the majority of the cases investigated (61.5\%), the infection had been present for a long time, with a mean duration of 11 years. Direct mycological examination was performed in $86.2 \%$ of the patients $(n=56)$. Of these, $96.4 \%(n=54)$ tested positive. Culture and microculture were performed in vitro in 47 cases of those that tested positive at direct microscopy, results showing Fonsecaea pedroso $i$ to be the only agent present in this sample.

CONCLUSION: This study highlighted the extent to which chromoblastomycosis still affects the quality of life of the local population, principally individuals working in agriculture. This is a chronic disease for which there is no effective treatment. The importance of continuing to investigate this disease should be emphasized, as further studies may lead to new clinical or epidemiological findings.
\end{abstract}

Keywords: Chromoblastomycosis; Epidemiology; Fungi; Granuloma

Resumo: Fundamentos: A cromoblastomicose é uma infecção fúngica crônica, causada por fungos da família Dematiaceae, sendo Fonsecaea pedrosoi a mais comum, segundo vários estudos. É mais frequente em países tropicais e o estado do Pará possui grande casuística mundial. A doença é de difícil tratamento e apresenta recorrência frequente.

OBjETIVOS: Descrever os aspectos epidemiológicos, micológicos e formas clínicas dos casos de cromoblastomicose procedentes do estado do Pará - Brasil. MÉTODos: Foram realizados exames micológicos (direto, cultura e microcultivo) e observação clinicoepidemiológica em 65 pacientes do Serviço de Dermatologia da Universidade Federal do Pará, atendidos no período de 2000 a 2007. Empregou-se a classificação clínica proposta por Carrión em 1950.

RESUlTADOS: Os pacientes eram, em sua maioria, homens (93,8\%), lavradores (89,2\%), faixa etária entre 45-55 anos, com predominância de lesões verruciformes $(55,4 \%)$, localizadas principalmente nos membros inferiores $(81,5 \%)$. A maioria dos casos pesquisados $(61,5 \%)$ apresentou um longo tempo de doença, com uma média de 11 anos. O exame micológico direto foi realizado em $86,2 \%$ ( $\mathrm{n}=56$ ) dos pacientes; destes, 96,4\% ( $n=54)$ apresentaram resultado positivo. Foram realizados cultura e microcultivo in vitro de 47 pacientes com exame micológico positivo e os resultados mostraram o Fonsecaea pedrosoi como único agente etiológico identificado nesta amostra.

Conclusão: Este estudo mostrou o quanto a cromoblastomicose ainda compromete a qualidade de vida da população local, principalmente a de indivíduos que trabalham em lavouras, cursando com evolução crônica e sem tratamento eficaz. Observa-se a importância de dar continuidade a este estudo, o que poderá proporcionar novas contribuições clínicas ou epidemiológicas.

Palavras-chave: Cromoblastomicose; Epidemiologia; Fungos; Granuloma

Received on 23.01.2011

Approved by the Advisory Board and accepted for publication on 23.05.2011.

* This study was conducted at the Santa Casa de Misericórdia Foundation of Pará (FSAMPA) and the Dermatology Department of the Federal University of Pará (UFPA) - Belém (PA), Brazil.

Financial Support: None.

Conflict of Interests: None.

Master Degree, Assistant Professor I, Federal University of Pará (UFPA) and State University of Pará (UEPA) - Belém (PA), Brazil.

Dermatologist and Specialist in Infectious Diseases. PhD in Neurosciences and Cell Biology. Adjunct Professor, Federal University of Pará (UFPA) and State University of Pará (UEPA) - Belém (PA), Brazil.

MD, PhD in Pathology. Adjunct Professor, Federal University of Pará and State University of Pará (UEPA) - Belém (PA), Brazil.

Medical Degree awarded by the Federal University of Pará (UFPA) - Belém (PA), Brazil.

Undergraduate medical student, Federal University of Pará (UFPA) - Belém (PA), Brazil.

Dermatologist. Associate Professor, Federal University of Pará (UFPA) - Belém (PA), Brazil.

(C)2012 by Anais Brasileiros de Dermatologia 


\section{INTRODUCTION}

Chromoblastomycosis (CBM) is a slowly progressing, chronic fungal infection that affects the skin and subcutaneous cell tissue. Classified as a deep mycosis, the infection occurs following traumatic inoculation into the skin of pigmented fungal propagules of various species belonging to the Dematiaceae family found in the soil and in decomposing vegetables. ${ }^{1 .}$

In recent decades, advances have occurred in medical mycology, principally motivated by the impact of opportunistic fungal infections. The increase in the incidence and prevalence of these infections stimulated studies to be carried out to obtain more information in the fields of immunology, therapeutics and, principally, epidemiology, with the objective of preventing these infections and diagnosing them at an early stage. Nevertheless, similar advances have not been seen in relation to endemic subcutaneous fungal infections such as chromoblastomycosis, lacaziosis and eumycetoma. ${ }^{5}$

There are various obstacles to performing epidemiological studies on these diseases, principally the fact that they are less common compared to superficial and systemic infections. In addition, their coexistence with severe socioeconomic problems represents another barrier, since they predominantly affect populations in rural communities, often in tropical or subtropical regions of developing countries, for whom access to healthcare is difficult.

Of the infectious diseases affecting the rural Brazilian population, chromoblastomycosis is significant because of its associated morbidity. Progress of this disease is slow and the general health of the patient is usually preserved. However, in the great majority of cases the natural evolution of this infection results in deformity and functional incapacity of the affected limb. This makes chromoblastomycosis an extremely debilitating disease, with frequent episodes of secondary bacterial infections that lead to a significant reduction in the working capacity of affected patients, eventually resulting in their inability to work. This has a considerable negative effect on the lives of infected individuals and causes considerable losses to the workforce of the rural population. ${ }^{2 \cdot 4}$

Ideally, diagnosis should be made at an early stage when the infection is still treatable by surgical removal of the entire lesion, which remains the best method of treating this disease. Pharmacological treatment is prolonged, complicated and expensive, and relapses are common. In addition, it is difficult to monitor patients over the extended periods of time necessary in order to reach the criteria required to establish a clinical and mycological cure. ${ }^{1-4,6}$

The Amazon region is the area with the highest concentration of cases of chromoblastomycosis in Brazil. This is a rural area where individuals tend to have closer contact with vegetables and fruits in general and are, therefore, more exposed to the pathogen. Consequently, further information is required on the scope of this disease, its epidemiology and the clinical, mycological and histopathological characteristics of chromoblastomycosis in the state of Pará, a region in which the number of cases of this disease is considerably high.

Therefore, the general objective of the present study was to describe the epidemiological and mycological characteristics of the disease and its forms of clinical presentation in the state of Pará, Brazil.

\section{MATERIAL AND METHODS}

This epidemiological, observational, cross-sectional and descriptive study included 65 patients with chromoblastomycosis receiving care at the Dermatology Department, Tropical Medicine Center of the Federal University of Pará (UFPA) between January 2000 and July 2007. Diagnosis of these cases was made by clinical observation, direct mycological examination and histopathology of biopsies collected from scrapings of skin lesions.

Complete reviews were made of the patients' records in order to collect their clinical data such as the type of lesions, as well as any additional information on the patients such as age, gender, place of birth, type of employment, the location of the lesions on the patient's body and their size, the duration of the disease and any complications that developed.

Clinical diagnosis was based on the definitions described and proposed by Carrión in 1950 in which the lesions are divided into five different types (verrucous, nodular, plaque, cicatricial and tumoral).

\section{Collection of material for direct mycological exa- mination}

Scalpel blades were used for scraping the surface of the lesions, principally the more highly pigmented areas known as black dots. The material removed was spread onto a slide, clarified using $10 \%$ potassium hydroxide $(\mathrm{KOH})$ and examined under a microscope at 40x magnification. Muriform bodies or septate dematiaceous hyphae were noted.

For culture, Sabouraud dextrose agar was used as the medium for the primary isolation of the fungi under incubation conditions for four weeks. Following growth of the dematiaceous fungi, colonies were placed in potato agar for filamentation of the agent.

Following culture, microculture was performed on slides. Small segments of colonies were seeded in 
a $4.0 \mathrm{~mm}$-thick block of potato agar and placed on the surface of a slide covered with a sterile coverslip. The typical structures of the etiological agent were then observed using a common microscope with 40x magnification.

\section{RESULTS}

In this study, the epidemiological findings reveal a predominance of males (93.8\%), agricultural workers (89.2\%), individuals living in rural areas of the state of Pará (70.8\%) and individuals of 45 to 65 years of age (49.2\% of cases) (Table 1 ).

Based on Carrión's classification, the majority of the lesions (55.4\% of patients) had a verrucous appearance. The next most common clinical type of lesion consisted of plaques in $26.2 \%$ of patients, the nodular type in $7.7 \%$, cicatricial in $6.2 \%$ and tumoral lesions in $4.6 \%$ (Figure 1 and Graph 1).

As shown in graph 2, the lesions were most commonly located on the lower limbs (in $81.5 \%$ of cases). In the majority of the cases investigated

TABLE 1: Epidemiological characteristics of the cases of chromoblastomycosis seen at the Dermatology Department and Tropical Medicine Center of the Federal University of Pará (UFPA) between January 2000 and July 2007

\begin{tabular}{|c|c|c|}
\hline \multirow[t]{2}{*}{ Variables } & \multicolumn{2}{|c|}{ Cases } \\
\hline & $\mathbf{N}$ & $(\%)$ \\
\hline \multicolumn{3}{|l|}{ Age (years) } \\
\hline $25-45$ & 19 & 29.2 \\
\hline $45-65$ & 32 & 49.2 \\
\hline $65-85$ & 14 & 21.5 \\
\hline Total & 65 & 100.0 \\
\hline \multicolumn{3}{|l|}{ Gender } \\
\hline Male & 61 & 93.8 \\
\hline Female & 4 & 6.2 \\
\hline Total & 65 & 100.0 \\
\hline \multicolumn{3}{|l|}{ Profession } \\
\hline Agricultural worker & 58 & 89.2 \\
\hline Other & 7 & 10.8 \\
\hline Total & 65 & 100.0 \\
\hline \multicolumn{3}{|l|}{ Mesoregion } \\
\hline Lower Amazon & 0 & 0.0 \\
\hline Marajó & 2 & 4.2 \\
\hline Metropolitan area of Belém & 14 & 29.2 \\
\hline Northeastern Pará & 28 & 58.3 \\
\hline Southeastern Pará & 1 & 2.1 \\
\hline Southwestern Pará & 3 & 6.3 \\
\hline Total* & 48 & 100.0 \\
\hline
\end{tabular}

*Data missing: 17
(61.5\%), the disease had been present for a prolonged period, with a mean of 11 years.

Direct mycological examination was performed in 56 patients (86.2\% of cases). Of these, $96.4 \%$ $(n=54)$ tested positive. Due to operational problems, it was only possible to perform culture and microculture in vitro in 47 of the patients who had tested positive at direct microscopy (Figures 2 and 3). The results of culture showed Fonsecaea pedrosoi to be the most prevalent etiological agent, affecting 42 patients (77.8\% of cases). In the remaining cases, there were fungal contaminants. In none of these cases was Cladophialophora carrionii the agent.

\section{DISCUSSION}

In this study, the variables evaluated were important for obtaining further information on this disease and may serve as essential elements for a discussion on the role of epidemiology in this infection and on the use of the clinical classification of chromoblastomycosis proposed by Carrión in 1950 .

With respect to epidemiology, in general the findings of this study were similar to those reported in the literature. The infection was found principally in males, in agricultural workers and in individuals from rural areas of the state. These characteristics may be correlated with each other, since the fungus that causes this infection is present in the soil and in vegetables, and the fundamental triggering factor of chromoblastomycosis is the transportation of the saprophytic fungus to the host's skin by macro or micro traumatic inoculation.

With respect to the slightly older age group of the patients in the present study at the time of diagnosis, this may be due to a delay between the onset of the infection and the patient seeking medical attention, since this is a predominantly rural population for

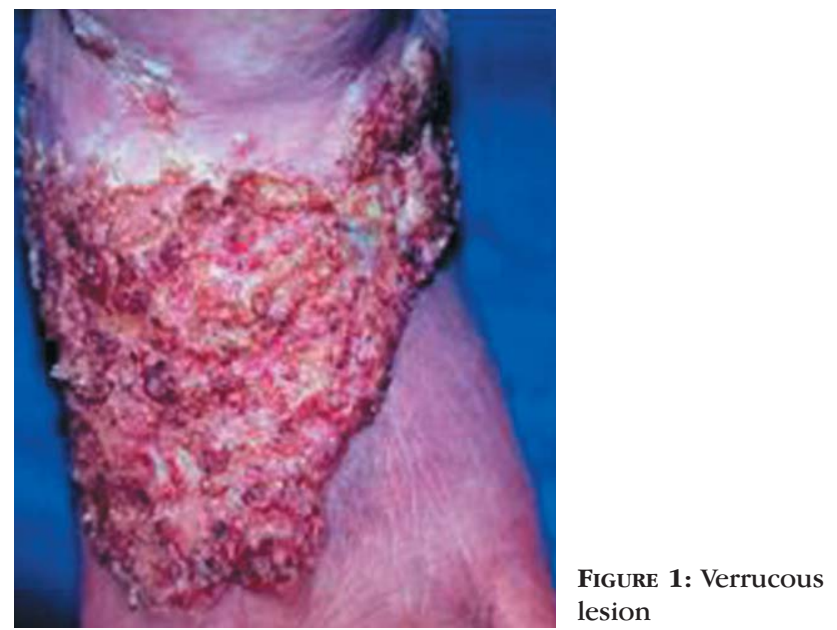




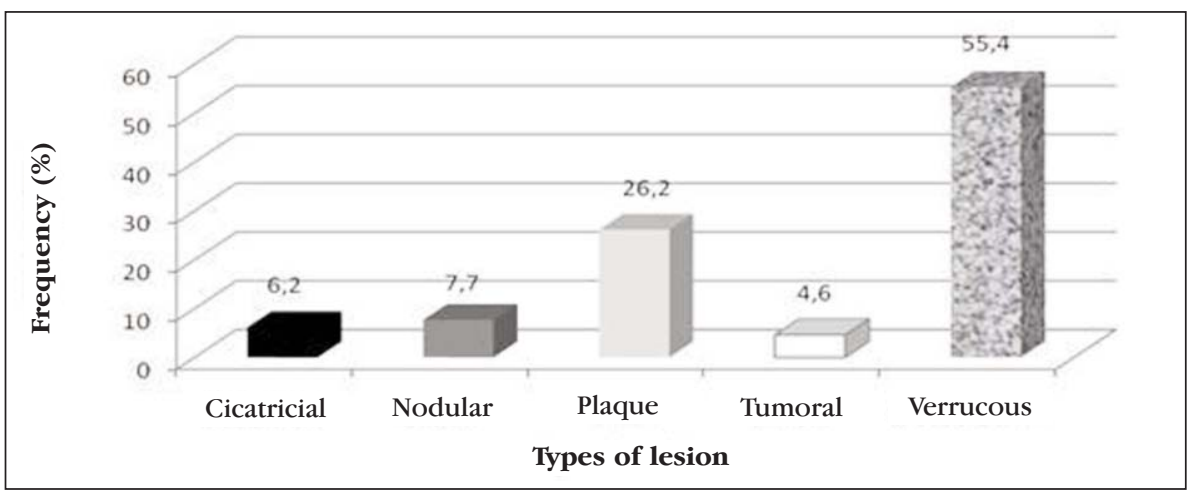

GraPH 1: Distribution of the patients with chromoblastomycosis seen at the Dermatology Department between January 2000 and July 2007 according to the type of lesion whom access to the secondary level of healthcare is difficult. In addition, few symptoms may be present in the initial stages of the disease and patients tend to try alternative natural therapies that are invariably ineffective. According to the literature, this is a chronic, slowly progressing disease that develops over a mean of 10 years. ${ }^{3,7,8}$

Attempts to cure the disease without seeking specialist medical attention may result in the patient being relatively older at diagnosis. Furthermore, the lesions are more severe from a clinical point of view at the time of diagnosis due to the prolonged duration of the disease and because of the inappropriate use of contraindicated irritants that may indeed cause modifications in the lesions such as eczematization and infections, further hampering diagnosis of the disease. The predominance of lesions on the lower limbs is also explained by the fact that the majority of these patients live in rural areas, living and working without adequate protection. The lower limbs are the area of the body that would be most likely to be in contact with material contaminated by fungi. ${ }^{1,3,7,9,10,11}$

The polymorphism of chromoblastomycosis lesions has attracted the attention of various authors who, at different times, have proposed different clinical classifications; however, Carrión's 1950 classification continues to be the most commonly used of these classifications and the one that is most widely accepted in the literature. ${ }^{12-15}$ Based on this classification, the majority of the lesions in the present study had a verrucous appearance, this type being present in more than half the cases (55.4\%). This finding is in agreement with almost all the publications in the literature reviewed for the present study such as, for example, the studies by Matte et al. (1996), Minotto et al., (2001) and Silva et al. (1992). 3,11 Very few studies, including that conducted in Mexico by Bonifaz and Carrasco-Gerard (2001), have reported a predominance of nodular lesions. ${ }^{16}$

Direct microscopy was positive in the majority of cases and this is in agreement with the findings of Bonifaz and Carrasco-Gerard (2001) and Minotto et al. (2001), highlighting the simplicity of diagnosing this disease, often without any need for methods of high complexity. Its characteristic muriform bodies are, in the majority of cases, easily scraped from the surface of the lesions and visualized using an optical microscope by trained, qualified professionals. This

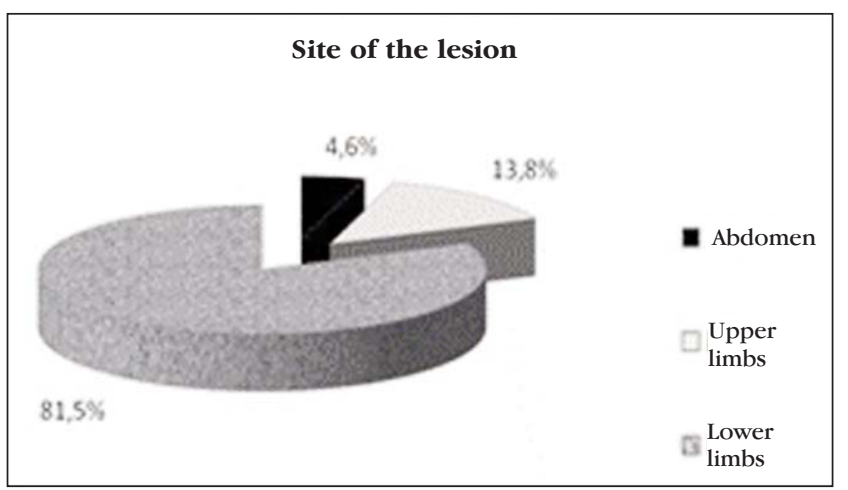

GrapH 2: Site of the lesion in the patients with chromoblastomycosis seen at the Dermatology Department between January 2000 and July 2007

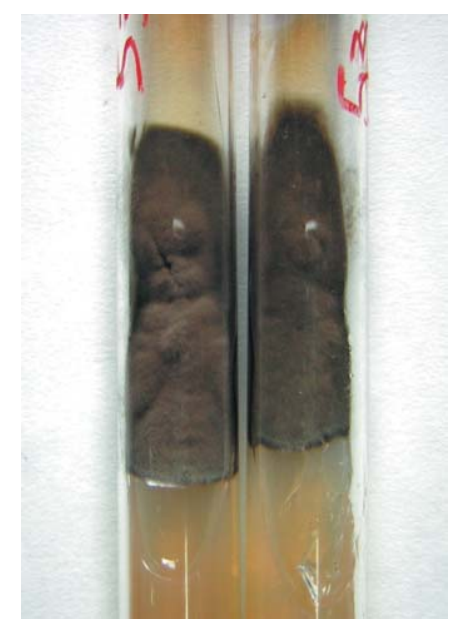

Figure 2: Velvety, darkbrown pigmented culture 


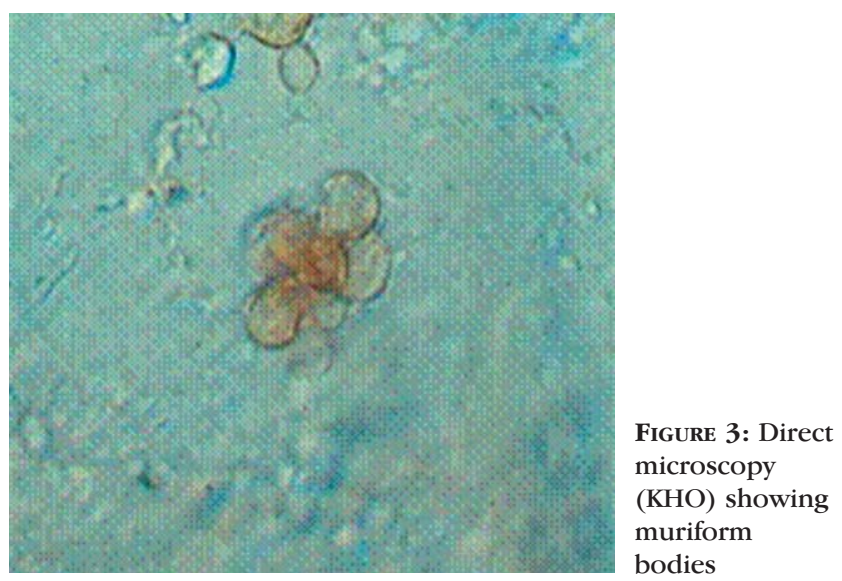

simple visualization of the structures of the etiological agent is related to the fact that this is an infection in which the fungal elements are eliminated through the skin (transepidermal elimination); hence they can be obtained by simply scraping the lesions. ${ }^{11,16}$

Transepidermal elimination in chromoblastomycosis was originally studied by Batres et al. (1978) when those authors were conducting a histopathological review of two cases of the disease and observed the presence of fungal structures in the stratum corneum (Figure 4). ${ }^{17}$ The phenomenon of transepidermal elimination was confirmed in the patients in the present study. This probably occurs because the epidermis plays an active role in eliminating fungi in some types of mycosis and the presence of a substance in the papillary dermis that is foreign to the organism is more easily removed by the epidermis without causing any major alterations or degeneration through a mechanism that remains to be fully clarified. This elimination of fungi through the epidermal layer also occurs with other mycoses such as lacaziosis and paracoccidioidomycosis. ${ }^{18,19}$

The most common agent present in the Pará region is believed to be Fonsecaea pedrosoi, as reported by Silva et al. in 1998 in a retrospective study conducted by those investigators of 325 cases that occurred over a 55-year period in the state of Pará. This species is also common in all the other regions of the country in which chromoblastomycosis has been investigated, since it is predominantly found in tropical and subtropical climates. ${ }^{3,5,7,10,11}$

No cases of infection by Cladophialophora carrionii were found. Esterre and Andriantsimahvandy (1997) studied chromoblastomycosis in Madagascar and reported finding this species in the southern region of the country. This finding was also reported by Sanchez-Mirt et al. (1995), who identified an endemic area for Cladophialophora carrionii in northeastern Venezuela. Both studies were conducted in arid

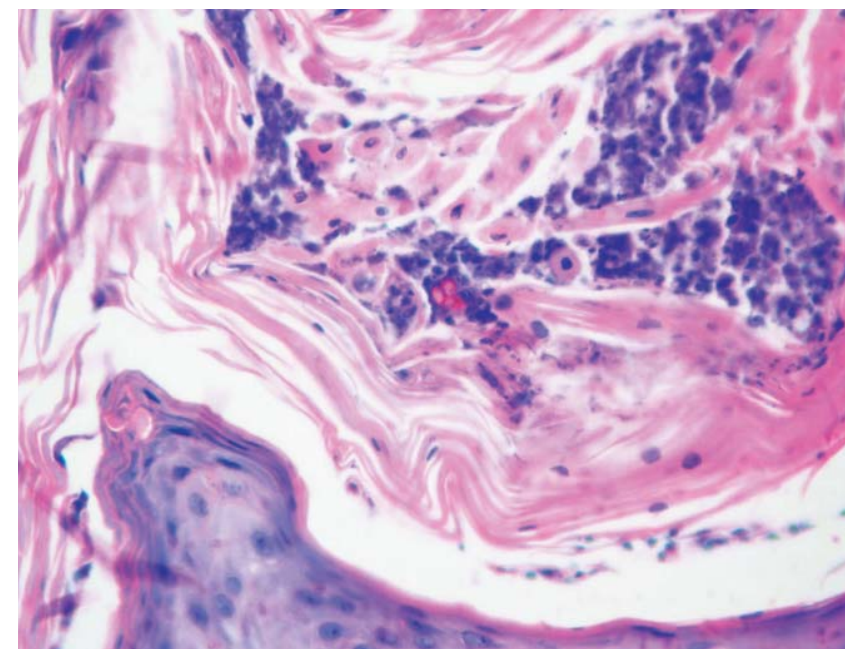

Figure 4: Photomicrography of a case of chromoblastomycosis showing details of the fungal structures in the stratum corneum. Hematoxylin-eosin, magnification $400 x$

regions that favor the growth of this species. Its predominance in arid regions of the world leads us to believe that this is why Cladophialophora carrionii is not characteristic of the Amazon region.

In the present study, patients with chronic lesions of more than 10 years' duration had more severe lesions, principally if they were of the verrucous type. In the majority of cases, cell immunity appears to be less competent when lesions are of the verrucous type. For this reason, they tend to be more severe, cover larger areas of the body and persist for longer periods of time due to the difficulty in treating the infection. In addition, repeated episodes of secondary bacterial infections represent a further complication.

This persistence and the capacity of the fungal cells to multiply in the dermis, as well as the greater exuberance of the inflammatory response in the case of verrucous lesions, is believed to be related to the inability of the organism to develop a more competent immune response.

It should be emphasized, however, that when no complications are present, chromoblastomycosis is a fungal infection that does not affect patients systemically, at least not extensively. Therefore, it is highly likely that their response to the stimulus of the invading agent is completely satisfactory; however, this is not what is seen. The actual reasons behind the inability of the organism to destroy the fungal structure in this infection remain to be clarified.

\section{CONCLUSION}

Although various studies have been conducted in recent decades on fungal infections in general, further studies are still required on the various clinical 
expressions presented by the host, and much is still to be learned on the clinical and etiological epidemiology of these infections. The present study shows the extent to which chromoblastomycosis still affects the quality of life of local populations and that the infection continues to affect individuals, predominantly those working in agriculture, resulting in a chronic infection with no effective treatment. The importance of conducting further studies should be emphasized, since they may provide new information, not only on the epidemiology of the disease but also on its clinical forms and on the immunology of the condition.

\section{REFERENCES}

1. Azulay RD, Azulay DR. Dermatologia. Rio de Janeiro: Guanabara Koogan; 2004 Capitulo 23, Cromomicose; p.287-8.

2. Sampaio SAP, Rivitti EA. Dermatologia. 2 ed. São Paulo: Artes Médicas; 2000. p. 545-7.

3. Silva ACCM, Serra Neto A, Galväo CES, Marques SG, Saldanha ACR, Silva CMP, et al. Cromoblastomicose produzida por Fonsecaea pedrosoi no Estado do Maranhão: I - aspectos clínicos, epidemiológicos e evolutivos. Rev Soc Bras Med Trop. 1992;25:37-44

4. Silva CMP, Rocha RM, Moreno JS, Branco MRFC, Silva RR, Marques SG, et al. 0 babaçu (Orbignya phalerata martins) como provável fator de risco de infecção humana pelo agente da cromoblastomicose no Estado do Maranhão, Brasil. Rev Soc Bras Med Trop. 1995;28:49-52.

5. Queiroz-Telles Filho F. Cromomicose. In: Talhari S, Neves RG. Dermatologia Tropical. São Paulo: Medsi; 1997. p.219-23.

6. Alviano DS, Franzen AJ, Travassos LR, Holandino C, Rozental S, Ejzemberg R, et al. Melanin from Fonsecaea pedrosoi of human antifungal antibodies and enhances the antimicrobial efficacy of phagocytes. Infec Immun. 2004;72:229-37.

7. Londero AT, Ramos CD. Cromoblastomicose no interior do Estado do Rio Grande do Sul. An Bras Dermatol.1989;64:155-8.

8. López Martínez R, Méndez Tovar LJ. Chromoblastomycosis. Clin Dermatol. 2007;25:188-94.

9. Carrión AL. Chromoblastomycosis. Ann N Y Acad Sc. 1950;50:1255-82.

10. Matte SMW, Lopes JO, Melo IS, Espadim LER, Pinto MS. Cromoblastomicose no Rio Grande do Sul: Relato de 12 casos. Rev Soc Bras Med Trop. 1997:30:309-11.

11. Minotto R, Bernardi CDV, Mallmann LF, Edelweiss MIA, Scroferneker ML. Chromoblastomycosis: a review of 100 cases in the state of Rio Grande do Sul. J Am Acad Dermatol. 2001;44:585-92

12. Brito AC. Lobomycosis. In: Tyring SK, Lupi 0, Hengge UR. Tropical Dermatology. Philadelphia: Elsevier; 2006. p.204-5.
13. Lacaz CS, Porto E, Martins JEC, Heins-vaccari EM, Melo NT. Tratado de Micologia Médica. 9 ed. São Paulo: Sarvier; 2002. p.441-61.

14. Queiroz-Telles F, McGinnis MR, Salkin I, Graybill JR. Subcutaneous mycoses. Infect Dis Clin North Am. 2003;17:59-85.

15. Ribeiro EL, Soares AJ, Ferreira WM, Cardoso CG, Naves PLF, Dias SMS Cromoblastomicose: Doença presente na realidade populacional brasileira. RBAC. 2006:38:189-92.

16. Bonifaz A, Carrasco-Gerard E, Saúl A. Chromoblastomycosis: clinical and mycologic experience of 51 cases. Mycosis. 2001;44:1-7.

17. Batres E, Wolf Jr JE, Rudolph AH, Knox JM. Transepithelial elimination of cutaneous chromomycosis. Arch Dermatol. 1978:114:1231-2.

18. Opromolla DVA, Belone AFF, Taborda PRO, Taborda VBA. Correlação clinicopatológica em 40 casos novos de lobomicose. An Bras Dermatol. 2000;75:425-34.

19. Uribe-J F, Zuluaga Al, Leon W, Restrepo A. Histopathology of chromoblastomycosis. Mycopathologia. 1989:105:1-6.

\author{
MAILING ADDRESS: \\ Carla Andréa Avelar Pires \\ Rua Bernal do Couto, 901 - Umarizal \\ 66080-200 Belém, PA, Brazil \\ E-mail: carlaavelarpires@bol.com.br
}

How to cite this article: Pires CAA, Xavier MB, Quaresma JAS, Macedo GMM, Sousa BRM, Brito AC. Clinical, epidemiological and mycological report on 65 patients from the Eastern Amazon region with chromoblastomycosis. An Bras Dermatol. 2012;87(4):555-60. 